The Journal of Engineering and Exact Sciences - jCEC, Vol. 06 N. 03 (2020)

journal homepage: https://periodicos.ufv.br/ojs/jcec

doi: 10.18540/jcecvl6iss3pp0387-0396

OPEN ACCESS - ISSN: 2527-1075

\title{
BUFFERING FUNCTION: A GENERAL APPROACH FOR BUFFER BEHAVIOR
}

\section{A.F. OLIVEIRA ${ }^{1 *}$}

${ }^{1}$ Universidade Federal de Viçosa, Department of Chemistry.

*Corresponding author. Universidade Federal de Viçosa, Department of Chemistry, Viçosa, Brazil, Phone: $+553136126610$

e-mail: andref.oliveira@ufv.br

\begin{tabular}{l} 
A R T I C L E I N F O \\
\hline Article history: \\
Received 2020-05-27 \\
Accepted 2020-09-04 \\
Available online 2020-09-04 \\
p a l a vr a $s$ - ch a ve \\
Poder Tamponante de Van Slyke \\
Capacidade Tamponante de \\
Kolthoff \\
Força do Tampão \\
Fração de Equilíbrio \\
$k$ e $y$ w or $d s$ \\
Van Slyke buffer value \\
Kolthoff buffer capacity \\
buffer strength \\
fraction of equilibrium
\end{tabular}

A B S T R A C T

Buffering systems are widely used in all areas of science that involve the use of aqueous solutions, such as pharmaceutical, environmental, and analytical chemistry. However, there are several approaches and parameters that can be employed to try to explain buffering behavior, such as the Van Slyke buffer value, Kolthoff's buffer capacity, acidity, alkalinity, and others but they are unable to provide a global explanation of it. In this paper, we propose the Buffering Function, which is a fundamental equation that enables explanation of all types of buffering behavior and existing parameters, without using of the HendersonHasselbalch approach.

\section{R E S UM O}

Sistemas tampão são amplamente usados em diversas áreas da ciência que envolvem soluções aquosas, tais como química farmacêutica, ambiental e analítica. Entretanto, há várias propostas e parâmetros que tentam explicar o comportamento tampão, tais como poder tamponante de Van Slyke, capacidade tamponante de Kolthoff, acidez, alcalinidade and outros, mas todos são incapazes de apresentar uma explicação global para esse comportamento. Neste artigo, propomos a Função Tamponante, que é uma equação fundamental que permite explicar todos os tipos comportamento tampão e os parâmetros já proposto, sem usar a Equação de Henderson-Hasselbach. 


\section{INTRODUCTION}

Buffer systems are very useful in many areas of chemistry, including biochemistry and medicinal, pharmaceutical, industrial, forensic, environmental, and organic chemistry. A generic definition of a $\mathrm{pH}$ buffer is a solution that provides resistance to variation of $\mathrm{pH}$ caused by the addition of a Brønsted acid or base. This type of solution usually contains a simple Brønsted acid-base system and the $\mathrm{pH}$ resistance occurs in a range of $\mathrm{pH}$ near a particular $\mathrm{pKa}$ value. Some buffer solutions include more than one system, such as McIlvaine's buffer (citrate and phosphate); BrittonRobinson; or universal buffer (and the resistance to variation of $\mathrm{pH}$ (or "pH resistance") is difficult to quantify. There are five associated factors that influence the $\mathrm{pH}$ behavior of a buffer solution: (i) the type of Brønsted acid-base system (or systems) in solution; (ii) the concentration of the system; (iii) the initial $\mathrm{pH}$ of the solution; (iv) the quantity of Brønsted acid or base added to the solution, which the buffer solution must "resist"; (v) the acceptable $\mathrm{pH}$ change of the buffer solution after its action, which depends on the application (for example, in an enzymatic system, it should be $0.5 \mathrm{pH}$ unit or less). (Oliveira, $2009 ; 2013,2020)$. Thus, the parameters for evaluation of buffer should explain all these factors.

The buffering efficiency of a solution is difficult to express, not least due to the various parameters that can be employed for this purpose. These include the buffering power ( $\beta$ ), proposed by Van Slyke (1922), the buffer capacity (BC) of Kolthoff (1937), and the buffer strength or effective buffer capacity (q $\Delta \mathrm{c}$ ) (Oliveira, 2009). Furthermore, additional confusion is introduced due to the different names used for these parameters (such as buffer power, buffer index, buffer intensity, and others) (Albert \& Serjeant, 1984; Guenther, 1975; Skoog et al., 1988; Harris, 2013; Stumm \& Morgan, 1995; Essington, 2003).

The Van Slyke buffer value, which has been widely discussed in the literature, expresses the added amount of a strong base or acid $(n)$ required to cause an infinitesimal variation of $\mathrm{pH}$, in a defined volume of solution (V) (Eq. 1).

$$
\beta=\frac{1}{V} \frac{d n}{d p H}
$$

This parameter is extensively used for qualitative interpretation, enabling evaluation of the range of $\mathrm{pH}$ where there is greatest buffering. However, it does not describe the behavior of buffer solutions to which finite quantities of strong acid or base are added. In this case, its integration is required, which is very complicated, even for simple systems.

The IUPAC has used the Kolthoff interpretation of the Van Slyke buffer value, called the buffer capacity (BC) (Chiriac et al., 1997; Thompson et al., 1981), which has sometimes been considered synonymous of the former. It expresses the amount $(n)$ of strong base needed to cause variation of $\mathrm{pH}$ equal to one unit. The difference between the two values is subtle and integration is needed for other variations of $\mathrm{pH}$.

Several methods have been proposed for the calculation of buffer values (or buffering capacities) and the evaluation of buffer solutions. A difficulty is related to the complicated mathematical procedures involved, which may be specific to each system, making it difficult to generalize (Asuero, 2007; Chiriac et al., 1997; Ming, 1984; Thompson et al. 1981; Urbansky et al. 2000). A subtler problem is that the determination of a buffer value requires use of a substance external to the system studied.

The buffer strength is an important parameter for evaluation of the amount of a strong acid (or base) needed to alter the $\mathrm{pH}$ in a defined range (and to obtain a certain initial $\mathrm{pH}$ value). It has been expressed by integral of buffer power and called the integral capacity (Ming, 1984), the neutralization capacity (Stumm et al., 1995; Essington, 2003). Oliveira $(2009,2020 \mathrm{a})$ presented a simple calculation procedure for this parameter that could be applied to buffer solutions formed by one or several Brønsted acid-base monoor polyprotic systems. This parameter is more practical than the buffer value (or capacity) but is still defined in terms of substances external to the solution studied.

In this work, we propose the use of a new parameter, the Buffering Function $(\tau)$, from which the parameters described above can be obtained and that can be applied to acid-base titrations and measurements of solution $\mathrm{pH}$ and alkalinity, among other applications.

\section{THEORETICAL FUNDAMENTATION}

Definition of the Buffering Function requires consideration of some important parameters related to the chemistry of solutions in equilibrium, such as the equilibrium fraction (also incorrectly called molar fraction or degree of dissociation, ionization, or association) and the effective electric charge (or simply effective charge), obtained from the charge balance. The calculation of concentrations of a buffer (simple or mixed) can be performed without use of equations such as the Henderson-Hasselbalch equation.

In a solution in equilibrium, the electric charge balance must be satisfied according to the Electroneutrality Principle. This means that for a solution with a specified $\mathrm{pH}$, the equilibrium positive charge concentration must be equal to the equilibrium negative charge concentration. The electric charge concentration due to an ion $i$, it means its contribution, is equal to the product of its charge $\left(q_{i}\right)$ and its equilibrium concentration. Thus, the electric charge balance will be represented by sum of all contribution terms (Eq. 2).

$$
\sum q_{i}[i]=0
$$

The equilibrium concentration of a chemical species belonging to a Brønsted acid-base system is directly associated with its analytical concentration (c) (or the analytical concentration of the system), considering its equilibrium fraction $(\alpha)$ (Eq. 3). This parameter, in turn, only depends on the $\mathrm{pH}$ of the solution (which is known) and the pKa values for the Brønsted acid-base system.

$$
\alpha_{j}(0)=\frac{[i]}{c(i)}
$$


In Eq. 3, the subscript $j$ indicates the number of protons lost from the totally protonated species present in the system.

The expressions used for the calculation of equilibrium fraction are quite complex (based on mass balance and the law of mass action), but can be easily performed using electronic spreadsheets available in software products such as Microsoft Excel, R, Scilab, or MATLAB. An add-on for Microsoft Excel is available for this purpose (Oliveira, 2020b).

The equations for calculation of the general polyprotic equilibrium fraction are shown in Eq. 5, while those for a simple monoprotic system are shown in Eq. 6.

$$
\begin{aligned}
& \alpha_{o}=\frac{1}{1+\sum_{j-1}^{N} 10^{i p H-\Sigma_{i}^{j} p i}} \\
& \alpha_{i}=\alpha_{0} 10^{i p H-\Sigma_{1}^{j} p N i} \\
& \alpha_{0}=\frac{1}{1+10^{p H-p R_{2}}} \\
& \alpha_{1}=1-\alpha_{a}=\alpha_{a} 10^{\mathrm{pH}-\mathrm{pNa}}
\end{aligned}
$$

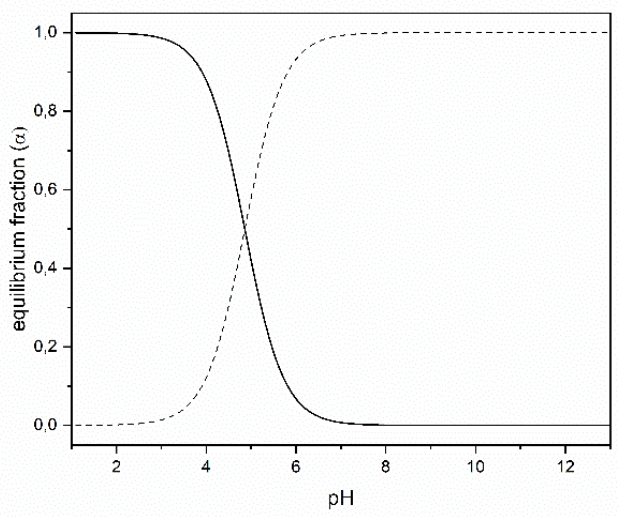

(A)

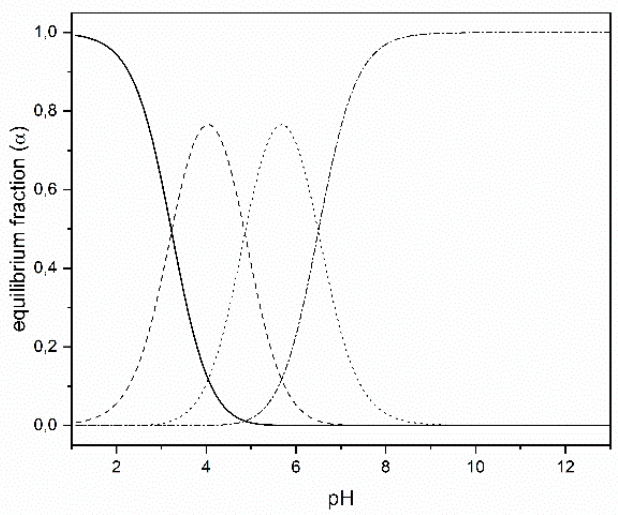

(B)

Figure 1. Species distribution diagrams for the acetate and citrate Bronsted acid-base system: (A) acetate; (B) citrate. (-) $\alpha_{0} ;(--) \alpha_{1} ;(\cdots) \alpha_{2} ;(---) \alpha_{3}$
Activity coefficients will be omitted in this paper. This correction could be performed correcting the equilibrium constants (Albert et al., 1984; Kotrly et al., 1985), while the proton concentration should be corrected for $\left[\mathrm{H}^{+}\right]=10^{-\mathrm{pH} /} / \gamma_{\mathrm{H}}$, where $\gamma_{\mathrm{H}}$ is the activity coefficient of the $\mathrm{H}^{+}$ion when a mixed equilibrium constant is used. Examples of species diagrams for the acetate and citrate Brønsted acid-base system are shown in Figure 1 .

The balance of charge can then be rewritten (Eq. 8).

$$
W a t+\sum \sigma_{i} \sigma_{i} c(i)=0
$$

where

$$
W a t=\left[H^{+}\right]-\left[O H^{-}\right]=10^{-p R}-10^{(p H-p N w)}
$$

And this term is always present in balance of charge (in aqueous solution). The strong electrolyte has an equilibrium fraction equal to one.

For a system $N$ in solution, the balance of electric charge could be expressed in Equation 9:

$$
W a t+\sum_{i=1}^{N}\left(\sum_{j=0}^{n} q_{j} \alpha_{j}\right) c(i)=0
$$

The sum of all the $q_{i} \alpha_{j}$ terms of the same Brønsted acid-base system is the effective charge, $q_{e}$ (Eq. 10). The effective charge can be interpreted as a weighted average of the charge of a system or the charge of a hypothetical species representing all the chemical species of the system.

$$
q_{e}=\sum_{j=0}^{n} q_{j} \alpha_{j}
$$

Where $n$ is the number of species in the system.

\section{Examples of charge balance}

Two examples of charge balance will be presented to assist in the subsequent discussion and definition of the Buffering Function. The thermodynamic constants were obtained from the compilation of critically selected equilibrium constants (Harris, 2007). For simplicity of presentation, as previously cited, the activity coefficient will not correct by ionic strength. The first of selected examples are a monoprotic solution, usually studied and the second one involves a mixture of monoprotic and polyprotic system. The goal is shown the strategy of calculation is the same, independently of number of Bronsted Acid-Base system in solution.

Solution of sodium acetate with analytical concentration of acetate equal to $c\left(A c^{-}\right)$and $\mathrm{pH}$ adjusted to 4.0 using hydrochloric acid

The chemical processes in the solution can be described by the following equations:

$$
\begin{array}{lrl}
\mathrm{H}_{2} \mathrm{O}_{(\mathrm{l})} \rightleftharpoons \mathrm{H}^{+}{ }_{(\mathrm{aq})}+\mathrm{OH}^{-}{ }_{(\mathrm{aq})} & \mathrm{pKw} & =14.00 \\
\mathrm{NaAc}_{(\mathrm{s})} \rightarrow \mathrm{Na}^{+}{ }_{(\mathrm{aq})}+\mathrm{Ac}_{(\mathrm{aq})}^{-} & & \\
\mathrm{HAc}_{(\mathrm{aq})} \leftrightharpoons \mathrm{H}^{+}{ }_{(\mathrm{aq})}+\mathrm{Ac}_{(\mathrm{aq})}^{-} & \mathrm{pKa} & =4.76 \\
\mathrm{HCl}_{(\mathrm{g})} \rightarrow \mathrm{H}^{+}{ }_{(\mathrm{aq})}+\mathrm{Cl}_{(\mathrm{aq})}^{-} & &
\end{array}
$$


The charge balance can be described as follows:

$$
\begin{aligned}
& {\left[\mathrm{H}^{+}\right]\left[\mathrm{OH}^{-}\right] \text {| }\left[\mathrm{Na}^{+}\right]\left[\mathrm{Ac}^{-}\right][\mathrm{Cl}]=0} \\
& 10^{\mathrm{H}}-10^{\mathrm{p}} \mathrm{pWW}^{\mathrm{W}}+\mathrm{c}\left(\mathrm{Na}^{3}\right)-\alpha_{1}, \mathrm{c}(\mathrm{Ac})-\mathrm{c}(\mathrm{Cl})=0 \\
& W a t+c\left(\mathrm{Na}^{+}\right)-\alpha_{1} \cdot c\left(\mathrm{Ac}^{-}\right)-c(\mathrm{HCl})=0
\end{aligned}
$$

The term $\left[\mathrm{H}^{+}\right]-\left[\mathrm{OH}^{-}\right]$will be present in all balances of charge in aqueous solutions and will be called the water contribution (Wat). Each term of this equation is called a contribution (of each system). The balance of charge could be used to calculate the analytical concentration of hydrochloric acid in the solution, if $\mathrm{c}\left(\mathrm{Ac}^{-}\right)$and $\mathrm{pH}$ are known, which is usually the case.

Solution of citric acid ( $\left.\mathrm{H}_{3} \mathrm{cit}\right)$ and sodium acetate ( $\left.\mathrm{Ac}^{-}\right)$, with pH adjusted to 4.0

In this second example, there is a polyprotic system and the compound used to adjust the $\mathrm{pH}$ is not known (it could be a strong acid or base, for example).

The chemical processes involved can be represented by the following equations:

$$
\begin{array}{lrl}
\mathrm{H}_{2} \mathrm{O}_{(\mathrm{l})} \rightleftharpoons \mathrm{H}^{+}{ }_{(\mathrm{aq})}+\mathrm{OH}^{-}{ }_{(\mathrm{aq})} & \mathrm{pKw} & =14.00 \\
\mathrm{NaAc}_{(\mathrm{s})} \rightarrow \mathrm{Na}^{+}{ }_{(\mathrm{aq})}+\mathrm{Ac}^{-}{ }_{(\mathrm{aq})} & & \\
\mathrm{HAc}_{(\mathrm{aq})} \leftrightharpoons \mathrm{H}^{+}{ }_{(\mathrm{aq})}+\mathrm{Ac}^{-}{ }_{(\mathrm{aq})} & \mathrm{pKa} & =4.76 \\
\mathrm{H}_{3} \mathrm{cit}_{(\mathrm{aq})} \leftrightharpoons \mathrm{H}^{+}{ }_{(\mathrm{aq})}+\mathrm{H}_{2} \mathrm{cit}^{-}{ }_{(\mathrm{aq})} & \mathrm{pK}_{1} & =3.128 \\
\mathrm{H}_{2} \mathrm{cit}^{-}{ }_{(\mathrm{aq})} \leftrightharpoons \mathrm{H}^{+}{ }_{(\mathrm{aq})}+\mathrm{Hcit}^{2-}{ }_{(\mathrm{aq})} & \mathrm{pK}_{2} & =4.761 \\
\mathrm{Hcit}^{2-}{ }_{(\mathrm{aq})} \leftrightharpoons \mathrm{H}^{+}{ }_{(\mathrm{aq})}+\mathrm{cit}^{3-}{ }_{(\mathrm{aq})} & \mathrm{pK}_{3} & =6.396
\end{array}
$$

The balance of charge is given by:

$$
\begin{aligned}
& {\left[\mathrm{H}^{+}\right]-\left[\mathrm{OH}^{-}\right]+\left[\mathrm{Na}^{+}\right]-\left[\mathrm{Ac}^{-}\right]+} \\
& -\left[\mathrm{H}_{2} \mathrm{cit}^{-}\right]-2\left[\mathrm{HCit}^{2-}\right]-3\left[\mathrm{cit}^{3-}\right]+\mathrm{q}_{\mathrm{x}} \mathrm{c}_{\mathrm{x}}=0
\end{aligned}
$$

where $\mathrm{q}_{\mathrm{x}} \mathrm{c}_{\mathrm{x}}$ is the contribution of counter-ions of strong acid or base used to adjust the $\mathrm{pH}$ to 4.0 , corresponding to the product of its effective charge and its analytical concentration. In the previous example, if the concentration of hydrochloric acid used was not known, $\mathrm{q}_{\mathrm{x}}$ would be -1 and $\mathrm{c}_{\mathrm{x}}$ would be equal to $\mathrm{c}(\mathrm{HCl})$.

$$
\begin{aligned}
& \text { Wat }+c\left(\mathrm{Na}^{+}\right)-\alpha_{1} \cdot c\left(\mathrm{At}^{-}\right)-\alpha_{1} \cdot d\left(\mathrm{H}_{2} \mathrm{cit}\right)+ \\
& -2 \alpha_{2}, c\left(\mathrm{H}_{3} c i t\right)-3 \alpha_{2}, c\left(\mathrm{H}_{2} c i t\right)+c_{\mathrm{x}} c_{\mathrm{x}}=0= \\
& W a t+c\left(\mathrm{Na}^{+}\right)-\alpha_{1} \cdot c\left(\mathrm{Ac}^{-}\right)+ \\
& +\left(-\alpha_{1}-2 \alpha_{2}-3 \alpha_{3}\right) \cdot c\left(H_{3} c i t\right)=-q_{x} c_{3} \\
& W a t+c\left(\mathrm{Na}^{+}\right)+\mathrm{q}_{t}\left(\mathrm{~A} \mathrm{r}^{-}\right) \cdot c(\mathrm{Ar}-)+ \\
& +q_{e}\left(\mathrm{H}_{3} \mathrm{cit}\right) \cdot \mathrm{c}\left(\mathrm{H}_{3} \mathrm{cit}\right)=-\mathrm{q}_{\mathrm{x}} \mathrm{c}_{\mathrm{s}}
\end{aligned}
$$

Since all the parameters on the left-hand side of the equation are known, the value of $\mathrm{q}_{\mathrm{x}} \mathrm{c}_{\mathrm{x}}$ may be calculated. If this term is positive, the counter-ion is a cation, so a strong base is used to adjust the $\mathrm{pH}$. If it is negative, then a strong acid is used.

In this example, the $q_{e}\left(A c^{-}\right)$is equal to $-0,1480$ (as show in previous example) and $q_{e}\left(H_{3}\right.$ cit $)$ is equal to $-1,0310$ (calculated by Alfa ${ }^{\circledR}$ add-on). Thus, again, if qx is higher than zero, it means ' $\mathrm{x}$ ' is a cation, and one has added the strong base for adjusting of $\mathrm{pH}$. If qx is lower than zero, one has added the strong acid, and finally, if qx is equal to zero, the solution already has the desirable $\mathrm{pH}$, without needing to adjust the $\mathrm{pH}$.
The equilibrium fraction and the effective charge depend only on the $\mathrm{pH}$ of the solution and the $\mathrm{pKa}$ values of the system, and they can be calculated using an electronic spreadsheet. Figure 2 shows the effective charge of each system plotted as a function of $\mathrm{pH}$. As expected, the curve for the effective charge of the acetate system shows negative values for the equilibrium fraction of acetate, varying from zero to -1 . The values for the citrate system vary from zero to 3 . These values reflect the predominance of the different species. For $\mathrm{pH}$ above $\sim 7.5$, the totally deprotonated ion $\left(\mathrm{cit}^{3-}\right)$ is predominant, so the value of $\mathrm{q}_{\mathrm{e}}$ is -3 . The solutions shown in both examples could be seen as buffer solutions. Intuitively, it is possible to observe that for addition of acid or base to these solutions, $\mathrm{pH}$ resistance will be associated with the increase of acid or base that changes the $\mathrm{pH}$ from the $\mathrm{pH}$ of the buffer to the $\mathrm{pH}$ after addition of acid or base. This indicates the strength of the buffer, which will be higher, for example, with high variation of $\mathrm{q}_{\mathrm{e}}$ between the two $\mathrm{pH}$ values. Hence, it can be seen from Figure 2 that the buffering range for acetate solution would be around $\mathrm{pH} 4.8$ (the $\mathrm{pKa}$ of the acetate system), while for the citrate system it would be from at least $\mathrm{pH} 2$ up to $\mathrm{pH} 7$.

\section{The Buffering Function $(\tau)$}

It can be seen from careful analysis of the charge balance that the terms Wat and the contributions of the Brønsted acid-base system are responsible for the buffering effect. Ions without variation of effective charge, as a function of $\mathrm{pH}$, will not have any influence.

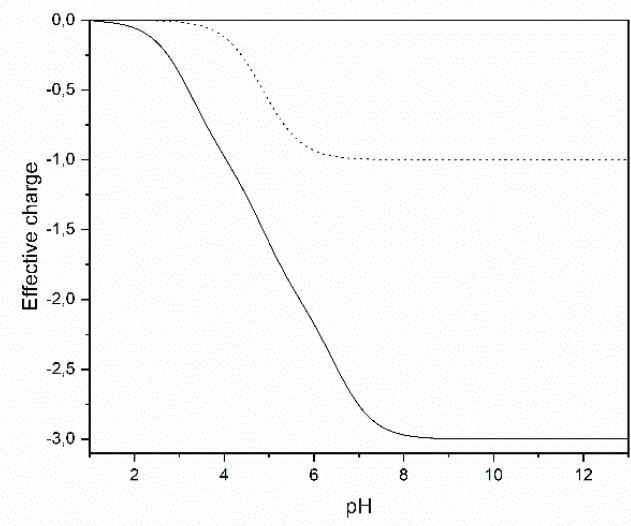

Figure 2. Effective charge of each Bronsted acid-base system, as a function of solution pH. (…) acetate; (-) citrate.

Accordingly, the Buffering Function $(\tau)$ may be defined as follows:

$$
\tau(p H)=W a t+\sum q_{o_{i}} c_{i}
$$

This simple function considers only the $\mathrm{pH}$ of the solution, the $\mathrm{pKa}$ values, and the analytical concentrations for each Brønsted acid-base system. The value obtained does not depend on the process used to produce the solution. For example, a solution of acetate at $\mathrm{pH} 4.0$ will have the same $\tau$ value irrespective of whether the solution was prepared using acetic acid adjusted with sodium hydroxide or using sodium 
acetate adjusted with hydrochloric acid (both at the same ionic strength). This is analogous to a state function.

The balance of charge can be rewritten as follows:

$$
\tau+q_{x} c_{x}+\sum q_{c} c_{c}=0
$$

where the subscript $c$ indicates the counter-ions of the Brønsted acid-base systems.

If a solution has no adjustment of $\mathrm{pH}$, the term $q_{x} c_{x}$ is zero. For example, the value of $\tau$ for a solution of $50 \mathrm{mmol} \mathrm{L}^{-1}$ sodium acetate is equal to $-50 \mathrm{mmol} \mathrm{L}^{-1}$. In the same way, the value of $\tau$ for a solution of $50 \mathrm{mmol} \mathrm{L}^{-1}$ acetic acid is equal to zero. These results are shown in Figure 3.

Figure 3B shows $\tau$, as a function of $\mathrm{pH}$, for solutions of the acetate system at an analytical concentration of 50 mmol L-1. The same curve shows the behavior of different solutions, including solutions prior to adjustment of $\mathrm{pH}$ and buffer solution with $\mathrm{pH}$ adjusted to $\mathrm{pH} 4.0$, already used as an example.

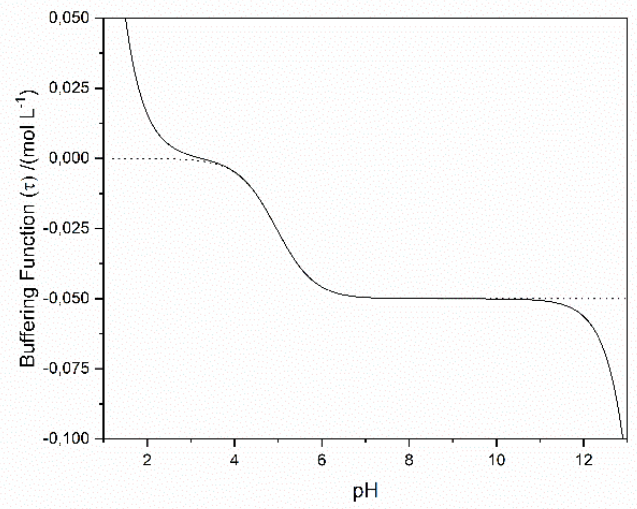

(A)

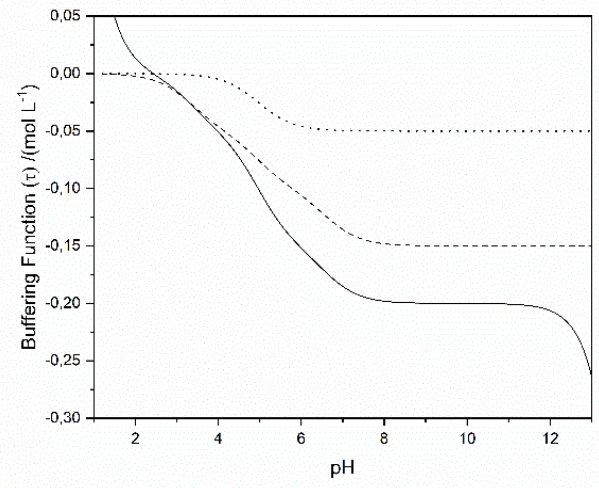

(B)

Figure 3. Buffering Function ( $\tau$ ) according to pH. (A) Buffer solution of $50 \mathrm{mmol} \mathrm{L}^{-1}$ acetate; $(\square) \tau$ total; (......) acetate system contribution; (-----) (B) buffer

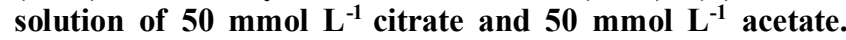
$(\square) \tau$ total; (......) acetate system contribution; (-----) citrate system contribution.

Figure $3 \mathrm{~A}$ shows the profile of the acetate system contribution and the buffering effect of the Wat term at extremes of $\mathrm{pH}$ (below $\mathrm{pH} \sim 2$ and above $\mathrm{pH} \sim 12$, where there are excesses of protons and hydroxyls, respectively). These regions are called pseudo-buffer regions ${ }^{1}$. In the same way as effective charge, the buffering is more intense in the region with greater slope, as discussed further below. The solution composed by two different systems, with acetate and citrate both at $50 \mathrm{mmol} \mathrm{L}^{-1}$, is presented in Figure $3 \mathrm{~B}$. The contribution of each system is shown, and it is possible to observe the large range of buffering of the solution below $\mathrm{pH}$ $\sim 7$, due also to the contribution of water (the Wat term).

The Buffering Function of a solution (denoted solution 3 ) obtained by mixing two other solutions (denoted 1 and 2), in the absence of reactions other than the acid-base equilibria, is the weighted average of these solutions:

$$
\tau_{3}\left(p H_{3}\right)=\tau_{1}\left(p H_{1}\right) f_{1}+\tau_{2}\left(p H_{2}\right) f_{2}
$$

where $f_{l}$ and $f_{2}$ are dilution factors.

The parameters associated with the evaluation or use of the buffers discussed previously will be defined based on the Buffering Function, demonstrating its fundamental importance.

\section{REDEFINITION OF BUFFER's PARAMETERS}

Buffer strength $(q \Delta c)$

The buffer strength describes the quantity of acid or base needed to vary $\mathrm{pH}$ between two values (initial and final values). Since a charge balance is defined for each $\mathrm{pH}$ condition, this parameter may be calculated considering the difference between the charge balances at each $\mathrm{pH}$. Therefore, it can be expressed (and defined) as a difference in the Buffering Function (Eq. 10)

$$
q \Delta c=\tau\left(p H_{A}\right) \quad \tau\left(p H_{D}\right)
$$

where subscripts $A$ and $B$ indicate the final (after variation of $\mathrm{pH}$ ) and initial (buffer solution) $\mathrm{pH}$ values, respectively.

The buffer strength is an especially important and practical parameter since it expresses the effective influence of the analytical concentration or $\mathrm{pH}$ variation of the systems present in solution. In the case described above, the buffer strength for each solution may be calculated directly using Figure 3 . Finally, this is, actually, a capacity parameter. So, the Kolthoff buffer capacity is just a particular case of the buffer strength (and buffer function) when the variation of $\mathrm{pH}$ is equal to one unit.

\section{Buffer value}

The buffer value $(\beta)$, defined by Van Slyke, is a limit situation of the buffer strength when a variation of $\mathrm{pH}$ tends to zero. It may be expressed using the Buffering Function $(\tau)$

$$
\beta=-\frac{1}{V} \frac{d n_{e}}{d p H}=-\frac{d \tau}{d p H}
$$

where the first definition requires knowledge of the volume of the solution and the amount of the external compound added to the solution $\left(n_{e}\right)$. The second definition, which uses $\tau$, only requires information about the buffer solution.

This parameter can be better understood by splitting it into two terms, one considering the water contribution and other considering the Brønsted acid-base systems: 


$$
\beta=-\frac{d W a t}{d p H}-\sum c_{i}\left(\frac{d q_{e, i}}{d p H}\right)
$$

Figure 4 shows the contribution of each system (citrate and acetate) in the solution used as an example, together with the water contribution (responsible for the pseudo-buffer region) and the total additive effect. It is important to point out that this parameter is most important for qualitative evaluation of the behavior of a buffer solution.

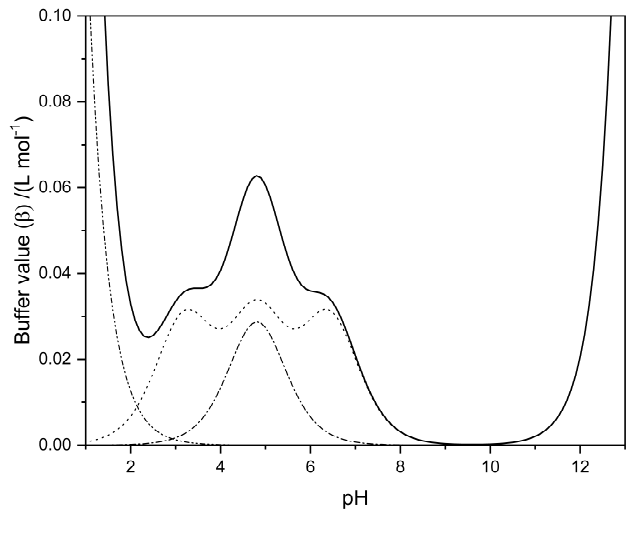

Figure 4. Van Slyke's buffer value, as a function of $\mathrm{pH}$. Contributions: water (pseudo-buffer region) (-..-..- ); acetate system (-.-.-); citrate system (.....); total $(-)$.

This is a useful parameter for qualitative evaluation of a buffer system, although there is great difficulty in attributing numerical values to experimental situations since it considers an infinitesimal variation and the linear region is very limited. For a wider range of $\mathrm{pH}$, the integration of this parameter should be needed (Ming, 1984, Stumm et al., 1995) so the use of buffer strength is much easier.

\section{Kolthoff's buffer capacity ( $\triangle B$ )}

Kolthoff's buffer capacity $(\Delta \mathrm{B})$, proposed in 1937, seems to have been an attempt to simplify use of the Van Slyke parameter. Instead of a differential equation, Kolthoff proposed the use of a finite variation of $\mathrm{pH}$, namely one $\mathrm{pH}$ unit, which may be easily expressed in terms of $\tau$ (Eq. 13).

$$
\Delta B=-\frac{\Delta \tau}{\Delta p H(=1)}=-(\tau(p H)-\tau(p H-1))
$$

At this point, it is useful to consider the different ways in which the efficiency of the buffer can be described (Ming, 1984; Oliveira, 2009; Stumm et al., 1995;). The term "capacity" has the meaning of a reservoir, or the quantity available to maintain an effect. Examples of this type of parameter are acidity, alkalinity, base (and acid) neutralizing capacity, and soil phosphate buffering capacity. In contrast, the term "intensity" is related to a specific value in a given situation, such as $\mathrm{pH}, \mathrm{E}_{\mathrm{h}}$, or the equilibrium concentration of a chemical species in solution.

Accordingly, the Van Slyke buffer value can be classified as an intensity parameter, while the buffer strength is a capacity parameter. Kolthoff's buffer capacity is difficult to classify. Under certain conditions, it could be considered a type of capacity parameter, although such conditions are limited. As an intensity parameter, it is very similar to the Van Slyke buffer value, but not for infinitesimal variation of $\mathrm{pH}$. Therefore, it seems likely that this parameter will fall into disuse, while buffer value and buffer strength will be used as the intensity and capacity parameters for buffer solutions, respectively. Furthermore, both can be obtained using $\tau$.

\section{Mixed buffer solutions}

Evaluation and prediction of the buffering effect in solutions with several Brønsted acid-base systems, such as mixed buffer solutions, is an important application of the Buffering Function. This function enables easier calculations for this type of solution, such as in the selection of suitable systems for mixing in a particular experimental situation.

Since the $\tau$ function considers the sum of the contributions of all the systems in the solution, the calculation of buffer strength can be performed in a wide $\mathrm{pH}$ range, while graphical evaluation may also be performed.

\section{McIlvaine buffer as an example}

The McIlvaine buffer, composed of phosphate and citrate systems, can be used as an example of a mixed buffer solution. Using classical calculation of buffer concentration, this presents an exceedingly difficult problem. A simple calculation of McIlvaine buffer composition using the XXI method was proposed (Oliveira, 2020c). However, it can be described using the Buffering Function, as follows:

$$
\tau=W a t+q_{\varepsilon}(\text { cit }) \cdot c(\text { cit })+q_{\varepsilon} \text { (phos) } \cdot c(\text { phos })
$$

where cit is the citrate system and phos is the phosphate system.

The Figure 5 shows the overall Buffering Function and the contributions of each system for a solution with analytical concentrations of $50 \mathrm{mmol} \mathrm{L}^{-1}$ for phosphate and citrate.

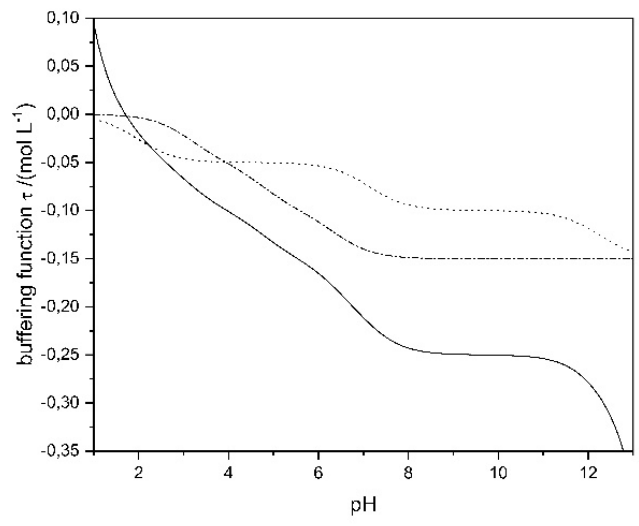

Figure 5. Buffering Function for a solution containing $50 \mathrm{mmol} \mathrm{L}^{-1}$ phosphate and $50 \mathrm{mmol} \mathrm{L}^{-1}$ citrate. Contributions: citrate (---); phosphate (…); total (--).

A buffering effect can be seen in a wide $\mathrm{pH}$ range $(\mathrm{pH}$ below 8.0). A pseudo-buffering range above $\mathrm{pH} 11$ can also be seen. In other words, the range of lowest buffering is between $\mathrm{pH} 8.0$ and $\mathrm{pH}$ 11.0. In addition, the $\mathrm{pH}$ resistance of a solution 
at a particular $\mathrm{pH}$ to the addition of another solution can be estimated directly from the graph. If a high buffering effect is required for a wider range of $\mathrm{pH}$, it is easy to propose other Brønsted acid-base systems for amplification of the range, such as the borate system ( $\mathrm{pKa} 9.24$ ), while better evaluation can be made of the analytical concentration.

\section{CONCLUSION}

There are several parameters that can be used to describe different aspects of buffer solutions or buffering effects. All these parameters may be obtained using the Buffering Function $(\tau)$, which consequently provides a more comprehensive evaluation of the system. Using this function, the Van Slyke buffer value, Kolthoff buffer capacity, and buffer strength parameters may be compared, and the confusion related to the Kolthoff parameter may be clarified. The Buffering Function can provide a more comprehensive explanation of $\mathrm{pH}$ effects associated with different situations or parameters, such as acid-base titration, alkalinity, acidity, base (or acid) neutralizing capacity, or even the $\mathrm{pH}$ of pure solutions. Finally, it can be easily determined using widely available computer software packages.

\section{ACKNOWLEDGMENTS}

The authors are grateful for the financial support provided by CAPES, FAPEMIG, and CNPq. We are also indebted to Professor João Carlos de Andrade (UNICAMP, retired) for his invaluable comments and suggestions for improving this manuscript.

\section{REFERENCES}

Albert, A.; Serjeant, E. P. The determination of ionization constants : a laboratory manual; Chapman and Hall, 1984.

Asuero, A. Buffer Capacity of a Polyprotic Acid: First Derivative of the Buffer Capacity and $\mathrm{pKa}$ Values of Single and Overlapping Equilibria. Crit. Rev. Anal. Chem., 2007, $37,269$.

Bard, A. J. Chemical Equilibrium; New York: Harper \& Row, 1966.

Bates, R. G.; Determination of pH: Theory and Practice, New York: Wiley \& Sons, 1973.

Chiriac, V.; Balea, G. ; Buffer Index and Buffer Capacity for a Simple Buffer Solution. J. Chem. Educ. 1997, 74, 937.

Essington, M. E. Soil and Water Chemistry - An Integrative Approach; $1^{\text {st }}$ ed.; Boca Raton: CRC Press, 2003.

Guenther, W. B. Chemical Equilibrium; Boston: Springer, 1975.

Harris, D. c Quantitative Chemical Analysis; $7^{\text {th }}$ ed.; New York: Freeman and Co., 2007.

Hemond, H. F. Acid Neutralizing Capacity, Alkalinity, and Acid-Base Status of Natural Waters Containing Organic Acids Environ. Sci. Technol. 1990, 24, 1486.

Kolthoff, I. M. Acid-Base Indicators; $1^{\text {st }}$ ed.; New York:
Macmillan and Co. Ltd., 1937.

Kotrly, S.; Sucha, L. Handbook of Chemical Equilibria in Analytical Chemistry; $1^{\text {st }}$ ed; Ellis Horwood Ltd, 1985.

Ming, D. Integral Capacity of Buffer, Mikrochimica Acta, 1984, 159.

Oliveira, A. F. Chemical Equilibrium in Solutions - Oriented to Application (In Portuguese); 1st ed.; Átomo: Campinas, 2009.

Oliveira, A. F. Chemistry of Solutions - Evaluation of Chemical Species in Aqueous Solutions (In portuguese); 1st ed.; Viçosa: Editora UFV, 2020a. In press

Oliveira, A. F. Chemical Equilibrium in Aqueous Solution $<$ https://en.solucaoquimica.com/ $>$ Accessed in July, 10, 2020 b.

Oliveira, A. F. Questioning the relevance of solution $\mathrm{pH}$ calculation Journal of Engineering and Exact Sciences, 2020, 6, 147.

Perrin, D. D.; Dempsey, B. Buffers for $\mathrm{pH}$ and metal ion control; London: Chapman and Hall, 1979.

Skoog D. A.; West, D. M.; Holler, F. J. Fundamentals of analytical chemistry; Saunders College Pub, 1988.

Van Slyke, D. D. ; On the measurement of buffer values and on the relationship of buffer value to the dissociation constant of the buffer and the concentration and reaction of the buffer solution. J. Biol. Chem. 1922, 52, 525.

Stumm, W.; Morgan, J. J. Aquatic Chemistry: Chemical Equilibria and Rates in Natural Waters; $3^{\text {rd }}$ ed., 1995.

Thmpson, B. M.; Kessick, M. A. On the Preparation of Buffer Solutions J. Chem. Educ. 1981, 58, 743.

Urbansky, E. T.; Schock, M. R. ; Understanding, Deriving, and Computing Buffer Capacity J. Chem. Educ. 2000, 77, 1640. 